\title{
EBSD Analysis of Undesired Phase Development in Solid Oxide Fuel Cell (SOFC) Lanthanum Strontium Manganese Oxide (LSM) / 8 mol\% Yttrium Zirconium Oxide (8YSZ) Cathodes During Long-Term Thermal Anneal
}

Nathan Canfield ${ }^{1 *}$, John Hardy ${ }^{11}$, Christopher Coyle ${ }^{1}$, and Jeffry Stevenson ${ }^{1}$.

1. Pacific Northwest National Laboratory, Applied Materials and Manufacturing Group, Richland WA, USA

* Corresponding author: Nathan.Canfield@pnnl.gov

SOFC's were prepared from four LSM-8YSZ based compositions: LSM-20-98 [( $\left.\mathrm{La}_{0.8} \mathrm{Sr}_{0.2}\right)_{0.98} \mathrm{MnO}_{3-\delta}-$ $\left.\left(\mathrm{Y}_{2} \mathrm{O}_{3}\right)_{0.08}\left(\mathrm{ZrO}_{2}\right)_{0.92}\right], \quad$ LSM-20-95 $\quad\left[\left(\mathrm{La}_{0.8} \mathrm{Sr}_{0.2}\right)_{0.95} \mathrm{MnO}_{3-\delta} \quad-\quad\left(\mathrm{Y}_{2} \mathrm{O}_{3}\right)_{0.08}\left(\mathrm{ZrO}_{2}\right)_{0.92}\right], \quad$ LSM-10-98 $\left[\left(\mathrm{La}_{0.9} \mathrm{Sr}_{0.1}\right)_{0.98} \mathrm{MnO}_{3-\delta} \quad-\quad\left(\mathrm{Y}_{2} \mathrm{O}_{3}\right)_{0.08}\left(\mathrm{ZrO}_{2}\right)_{0.92}\right]$, and $\mathrm{LSM}-20-90 \quad\left[\left(\mathrm{La}_{0.8} \mathrm{Sr}_{0.2}\right)_{0.90} \mathrm{MnO}_{3-\delta} \quad-\right.$ $\left(\mathrm{Y}_{2} \mathrm{O}_{3}\right)_{0.08}\left(\mathrm{ZrO}_{2}\right)_{0.92}$. A fifth set of cells was procured with cathodes prepared by a commercial vendor, Fuel Cell Materials [Lewis Center, OH] LSM-20-95 FCM [(La0.8 $\left.\left.\mathrm{Sr}_{0.2}\right)_{0.95} \mathrm{MnO}_{3-\delta}-\left(\mathrm{Y}_{2} \mathrm{O}_{3}\right)_{0.08}\left(\mathrm{ZrO}_{2}\right)_{0.92}\right]$.

Cells of each composition were placed into furnaces and heated to $800^{\circ} \mathrm{C}, 900^{\circ} \mathrm{C}$, or $1000^{\circ} \mathrm{C}$. One cell of each composition was then removed from the furnaces at each temperature after 1000, 2000, 4000, 8000,12000 , and 16000 hours for EBSD analysis. For cells thermally annealed to $800^{\circ} \mathrm{C}$, regardless of time, no undesired phases were noted. There were two undesired phases found in cells thermally annealed to $1000^{\circ} \mathrm{C}-$ monoclinic zirconia $(\mathrm{MZrO})$ and strontium chromate $\left(\mathrm{SrCrO}_{4}\right)$. For cells thermally annealed at $900^{\circ} \mathrm{C}$, only LSM-20-90/YSZ showed a very small $(0.5 \%)$ concentration of $\mathrm{SrCrO}_{4}$. Therefore, only the cells thermally annealed at $1000^{\circ} \mathrm{C}$ will be discussed.

Chemical characterization of all cells using EDS did not find any unexpected phases in the LSM/YSZ cathodes. MZrO would not be detected by EDS, because this phase has the same elemental composition as the YSZ in the cathode. For $\mathrm{SrCrO}_{4}$, it is likely that the large beam interaction volume with the sample, and the small concentration of $\mathrm{Cr}$ in that volume, detection limits preclude distinguishing $\mathrm{Cr}$ from background. However, due to the superior spatial resolution and very shallow surface sampling depth of EBSD, detection of the $\mathrm{MZrO}$ and $\mathrm{SrCrO}_{4}$ phases was easily achieved.

Figure 1 shows the concentration of $\mathrm{MZrO}$ and $\mathrm{SrCrO}_{4}$ as a function of thermal annealing time for each cathode composition. Figure 1a shows that $\mathrm{MZrO}$ concentration varies widely with time for all $\mathrm{LSM} / \mathrm{YSZ}$ compositions at $1000^{\circ} \mathrm{C}$. Figure $1 \mathrm{~b}$ shows a generally increasing trend in $\mathrm{SrCrO}_{4}$ content for the three prepared LSM20/YSZ cathodes (i.e. LSM20-98, 20-95, and 20-90). The LSM20-95/YSZ FCM commercial cathode showed no $\mathrm{SrCrO}_{4}$ concentration until $16000 \mathrm{hrs}$ at $1000^{\circ} \mathrm{C}$. The LSM1098/YSZ cathode material showed no $\mathrm{SrCrO}_{4}$ phase development up to $16000 \mathrm{hrs}$.

The $\mathrm{SrCrO}_{4}$ appears to be most prevalent in the LSM20-90/YSZ, while the LSM20-95 and LSM2098/YSZ appear to have far less of the $\mathrm{SrCrO}_{4}$ phase - possibly indicating that decreasing Lanthanum and Strontium concentration relative to Manganese could potentially promote $\mathrm{SrCrO}_{4}$ formation. Furthermore, the LSM-10-98/YSZ cathode has reduced Strontium content relative to Lanthanum compared to LSM-20-98/YSZ, which resulted in the least/no $\mathrm{SrCrO}_{4}$ formation.

Discovery of $\mathrm{SrCrO}_{4}$ in the cathode materials requires a source of $\mathrm{Cr}$ contamination. The most likely source is exposed Ni80Cr20 heating elements in the furnaces used for thermal annealing of the cells. 
FactSage was used to calculate $\mathrm{Cr}$ species vapor pressures based on local average relative humidity of $80.4 \%$ and average temperature of $52.9^{\circ} \mathrm{F}$, which equates to an average water partial pressure of 0.0109 atm. Assuming either $\mathrm{NiCr}_{2} \mathrm{O}_{4}$ or $\mathrm{Cr}_{2} \mathrm{O}_{3}$ scale formation on the Ni80Cr20 elements, the $\mathrm{Cr}$ vapor pressure would fall within a range of $4.03 \mathrm{E}-7$ to $7.00 \mathrm{E}-4$ atm at $1000^{\circ} \mathrm{C}$.

Unfortunately, for samples with thermal annealing times up to 12000 hours, furnace locations of cells were not tracked. Therefore, variability in concentration of $\mathrm{SrCrO}_{4}$ as a function of time are thought to be due to differing proximity of the cells to the heating elements causing differences in the $\mathrm{Cr}$ concentration in the local environment of each cell. For instance, if the cells extracted from the furnace after 8000 hour cells for the LSM20-98 and LSM20-95/YSZ cells were substantially closer to the heating elements than similar cells extracted after 12000 hours, it is reasonable to assume that more $\mathrm{SrCrO}_{4}$ could have formedin the 8000 hour sample than in the 12000 hour sample. Variation in $\mathrm{MZrO}$ content in the cathodes appears quite random, and may be due to destabilization of the YSZ, as the sole purpose of the $8 \mathrm{~mol} \%$ yttrium addition to the zirconium oxide is to lock the cubic phase of the lattice and prevent phase changes with temperature. Monoclinic is the stable phase of unstabilized zirconium oxide at room temperature.

Additional cells are continuing to run beyond 16000 hours for each composition, and locations of each cell will be tracked to attempt to validate this hypothesis, and to see how undesired phase development continues with additional thermal annealing time for all cathode compositions. It is hoped that these additional tests will lead to a more complete understanding of $\mathrm{SrCrO}_{4}$ formation in LSM/YSZ cathodes.

(a)

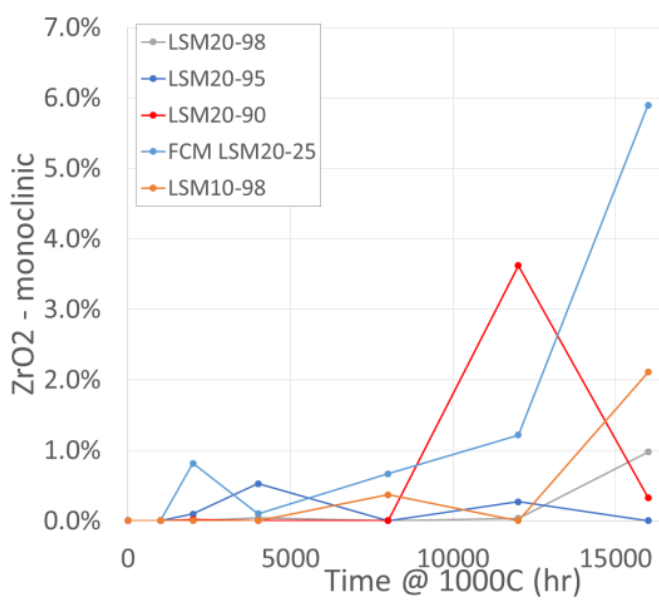

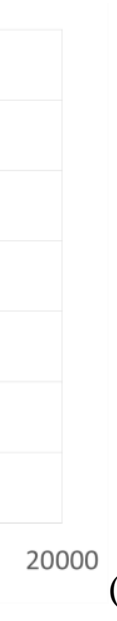

(b)

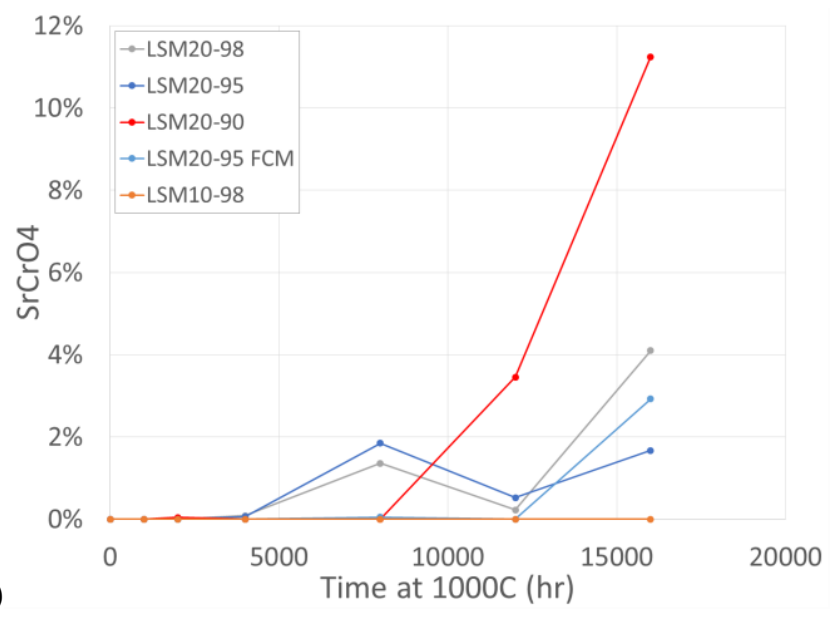

Figure 1. Concentrations of (a) monoclinic zirconia and (b) strontium chromate discovered by EBSD in $\mathrm{LSM} / \mathrm{YSZ}$ cathodes after thermal annealing at $1000^{\circ} \mathrm{C}$ for various times. 